\title{
Model Kegiatan Dakwah di Instansi TNI AU
}

\author{
Nur Hamidah Garini Putri ${ }^{1 *}$, Ahmad Agus Sulthonie ${ }^{1}$, Dindin Solahudin ${ }^{2}$ \\ 1Jurusan Komunikasi dan Penyiaran Islam, Fakultas Dakwah dan Komunikasi, UIN Sunan \\ Gunung Djati, Bandung \\ ${ }^{2} J u r u s a n$ Manajemen Dakwah, Fakultas Dakwah dan Komunikasi, UIN Sunan Gunung Djati, \\ Bandung \\ *Email : gariniputri8@gmail.com
}

\begin{abstract}
ABSTRAK
Tulisan ini bertujuan untuk mengetahui model kegiatan dakwah dengan ragam kegiatan kbithobah di Lanud Wiriadinata Tasikmalaya melalui proses, bentuk dan faktor pendukung yang bisa dijadikan contoh oleh instansi lain di Indonesia, khususnya instansi TNI AU. Penelitian yang dilakukan menggunakan metode deskriptif pendekatan kualitatif. Metode ini digunakan untuk memaparkan dan menceritakan fakta-fakta yang terjadi pada kegiatan khithobah di Lanud Wiriadinata melalui tahap observasi dan wawancara. Hasil penelitian proses kegiatan kbithobah di Lanud Wiriadinata dilakukan secara bertahap yaitu: perencanaan, pengorganisasian, pelaksanaan dan evaluasi. Bentuk dakwah yang digunakan dalam kegiatan tersebut dengan cara pembinaan yang disampaikan melalui Tabligh Khithobah. Dan yang menjadi faktor pendukung kegiatan tersebut secara internal dari Personel Lanud Wiriadinata dan secara eksternal dari lingkungan sekitar.
\end{abstract}

Kata Kunci : Model Dakwah; Khithobab; Instansi TNI AU

\section{ABSTRACT}

The purpose of this paper is to know the model of dakwah activities with various khithobah activity in Lanud Wiriadinata Tasikmalaya through the process, shape and supporting factors that can be used as examples by other agencies in Indonesia, especially for TNI AU. This research conducted using descriptive qualitative approach method. This method is used to explain and tell facts about the facts that occurred in the activity of khithobah in Lanud Wiriadinata through the observation and interview stages. The research's result of kbithobah activity process in Lanud Wiriadinata is done gradually, that is: planning, organizing, implementing and evaluating. The form of dakwah used in the activity by means of coaching through Tabligh Khithobah. And the supporting factors in this activity internally are the personnel of Lanud Wiriadinata and externally is the surrounding environment.

Diterima: Januari 2018. Disetujui: Februari 2018. Dipublikasikan: Maret 2018

56 
Keywords : Dakwah Model, Khithobah, TNI AU Agencies

\section{PENDAHULUAN}

Di Indonesia, kegiatan dakwah banyak dilakukan melalui berbagai macam potensi baik formal maupun non formal, seperti instansi-instansi dakwah Islam, organisasi-organisasi remaja masjid, kelompok-kelompok pengkajian Islam, dan yayasan-yayasan pendidikan Islam. Meskipun kemunculan instansi-instansi keislaman tersebut memiliki watak dan identitas yang berbeda, namun mereka mempunyai tujuan yang relatif sama, yakni untuk memberikan bimbingan, tuntunan, dan pengajaran agama Islam kepada masyarakat (Muhyiddin, dkk, 2014: 86).

Seiring berjalannya waktu, kegiatan dakwah berkembang menjadi model perkembangan gerakan jamaah yang diformulasikan kembali dalam era kekinian dan mengikuti perkembangan masyarakat yang dilandasi oleh perkembangan ilmu pengetahuan dan teknologi. Dengan perkembangan tersebut banyak model kegiatan dakwah yang dapat dilakukan.

Dalam ilmu komunikasi model adalah representasi suatu fenomena baik nyata ataupun abstrak dengan mengedepankan unsur-unsur terpenting dari fenomena tersebut (Mulyana, 2013: 123). Aristoteles merumuskan bahwa model itu merupakan komunikasi ketika seorang pembicara menyampaikan pembicaraannya kepada khalayak dalam upaya mengubah sikap mereka (Mulyana, 2013: 145). Sedangkan dakwah ialah mengajak manusia kepada jalan Allah secara menyeluruh, baik dengan lisan, tulisan maupun dengan perbuatan sebagai upaya muslim untuk mewujudkan nilai- nilai ajaran islam dalam realitas kehidupan pribadi, keluarga, dan masyarakat dalam semua segi kehidupan secara menyeluruh sehingga terwujud khairul ummah (Enjang, 2009: 5).

Dari penjelasan di atas dapat diartikan bahwa model kegiatan dakwah merupakan suatu contoh, pola atau ragam kegiatan dakwah baik yang biasa dilakukan di instansi keislaman atau instansi umum lainnya. Banyak model kegiatan dakwah yang bisa dilakukan salah satunya dengan cara khithobah (public speaking).

Khithobah dapat diartikan sebagai upaya sosialisasi nilai-nilai Islam melalui media lisan. Dalam pelaksanaannya khithobah terbagi menjadi dua yakni khithobah al diniyah dan khithobah al ta'tsiriyah. Khithobah al diniyah yaitu jenis khithobah yang terkait langsung dengan pelaksanaan ibadah mahdhah. Sedangkan khithobah al ta'tsiriyah tidak terkait secara langsung dengan pelaksanaan ibadah mahdhah. (Sukayat, 2009: 94).

Melakukan kegiatan dakwah di instansi keislaman seperti di masjid ataupun madrasah sudah biasa terjadi. Karena di sinilah tempat yang biasa digunakan untuk berdakwah. Lain halnya dengan instansi umum seperti di 
perkantoran, perusahaan dan lain sebagainya, bukan tempat yang biasa digunakan untuk berdakwah. Sehingga, kegiatan dakwah ini bisa terjadi namun tidak sesering di masjid atau madrasah. Salah satu instansi umum yang melakukan ragam kegiatan dakwah adalah di Instansi TNI AU.

Di instansi TNI AU yang bertugas melakukan kegiatan dakwah yaitu Subsibintal. Subsibintal adalah pembantu Siwatpres dalam menyelenggarakan pembinaan mental personel. Dalam rangka pelaksanaan tugas tersebut, Subsibintal mempunyai tugas kewajiban sebagai berikut : 1) Menyelenggarakan pembinaan rohani melalui ceramah dan memperingati hari besar keagamaan. 2) mengurus pernikahan, perceraian dan rujuk personel. 3) melaksanakan upacara pemakaman. 4) melaksanakan penyumpahan. 5) mengajukan bahan pertimbangan dan saran kepada Kadispers tentang hal-hal yang berkaitan dengan bidang tugasnya (AU, 2017: 23). TNI AU yang dijadikan tempat penelitian oleh penulis adalah TNI AU Wiriadinata, karena disana terdapat ragam kegiatan dakwah yang menarik.

Lanud Wiriadinata merupakan salah satu tempat yang digunakan untuk Landas Pesawat yang ada di Tasikmalaya. Lokasinya terdapat di Jalan Letkol Basyir Surya Kecamatan Cibeureum Tasikmalaya. Lanud Wiriadinata ini merupakan peninggalan penjajahan Belanda dan Jepang dengan nama yang lebih popular yaitu Lapangan Udara Cibeureum Tasikmalaya (Sumaryadi, 2003: 27). ibeureum Tasikmalaya (Sumaryadi, 2003: 27).

Berdasarkan latar belakang masalah di atas, maka dapat dirumuskan beberapa masalah. Diantara rumusan masalah tersebut adalah sebagai berikut: Bagaimana proses kegiatan khithobah yang diselenggarakan di Lanud Wiriadinata? Bagaimana bentuk kegiatan khithobah yang diselenggarakan di Lanud Wiriadinata? Dan apa yang menjadi faktor pendukung dalam kegiatan khithobah di Lanud Wiriadinata?

Metode yang digunakan dalam penelitian ini adalah metode deskriptif. Metode deskriftif yaitu metode penelitian yang dilakukan dengan memaparkan situasi dan peristiwa atau melukiskan dan melaporkan untuk memperoleh gambaran yang sistematis dan faktual mengenai fakta-fakta, sifat-sifat serta fenomena-fenomena apa saja yang terjadi ketika ragam kegiatan khithobah di Lanud Wiriadinata sedang berlangsung. Dari mulai menceritakan dan menggambarkan proses kegiatan khithobah yang diselenggarakan di Lanud Wiriadinata. Kemudian, menceritakan dan menggambarkan bentuk-bentuk kegiatan dakwahnya. Serta menceritakan dan menggambarkan faktor-faktor pendukung dalam pelaksanaan kegiatan dakwah tersebut.

Adapun hasil yang diperoleh dari pengumpulan data penelitian tersebut adalah diambil melalui observasi dan wawancara. Observasi yang dilakukan dengan cara berkunjung langsung ke lokasi yaitu di Lanud Wiriadinata 
Tasikmalaya. Karena model kegiatan dakwah di Lanud Wiriadinata ini beraneka ragam kegiatan kbithobahnya. Lanud Wiriadinata ini merupakan salah satu instansi umum yang melakukan kegiatan dakwah dengan beraneka ragam kegiatan khithobahnya walaupun personelnya masih kurang dalam pemahaman keagamaan. Salah satu kegiatan yang paling diamati adalah seputar kegiatan ragam kegiatan khithobah seperti kultum, ceramah mingguan, shalat berjamaah dan lain sebagainya. Selain itu, peneliti juga tidak lupa berkeliling di seputar kantor Lanud Wiriadinata sambil membawa catatan. Jadi, jika ada suatu hal yang penting langsung mencatatnya. Observasi ini tidak hanya dilakukan satu kali, melainkan beberapa kali sampai mendapatkan data-data yang diperlukan.

Setelah melakukan observasi, maka tahap selanjutnya adalah melakukan wawancara. Karena suatu data yang diperlukan tidak akan mudah didapat jika hanya melakukan observasi saja. Tetapi, untukmelengkapi dan mendapatkan data yang lengkap kita membutuhkan beberapa orang yang bisa diajak bicara melalui tanya jawab (wawancara) tentunya orang yang bersangkutan dengan penelitian.

Adapun orang-orang yang bersangkutan dalam penelitian ini adalah Kasubsi Bintal PNS Drs. Nurul Mutaqin, Komandan Letkol Pnb Safeano Cahyo Wibowo, S.T. Exc.Dipl.S.S., (Paroh) Perwira Rohaniawan PNS H. Agus Husen dan beberapa orang lainnya yang bisa menjelaskan beberapa hal seputar model kegiatan dakwah tentang ragam khithobah di Lanud Wiriadinata. Karena selain memberikan informasi, merekalah yang terlibat langsung dalam kegiatan tersebut. Sehingga dengan melakukan wawancara yang diajukan melalui beberapa pertanyaan akan mempermudah peneliti untuk mendapatkan data yang selengkap-lengkapnya. Selain itu, peneliti juga tidak lupa mendokumentasikan beberapa hal yang dianggap penting baik saat observasi lapangan atau wawancara.

\section{LANDASAN TEORITIS}

Teori yang dijadikan landasan dalam penelitian ini adalah teori model dakwah, khithobah, dan instansi. Model dalam Buku Pengantar Komunikasi menurut Aristoteles adalah bahwa model komunikasi ketika seorang pembicara menyampaikan pembicaraannya kepada khalayak dalam upaya mengubah sikap mereka (Mulyana, 2013: 123). Model merupakan suatu cara untuk menggambarkan atau menunjukkan sebuah objek tertentu yang berkaitan dengan berbagai aspek dari sebuah proses, pemikiran dan hubungan antara unsur pendukungnya. Sebuah model dapat dikatakan berhasil, apabila seluruh aspek mendukung terjadinya sebuah proses (Cangara, 2014: 43).

Secara garis besar, model terbagi menjadi dua bagian, yakni model operasional dan model fungsional. Model operasional yaitu menggambarkan 
suatu proses melalui pengukuran dan proyeksi kemungkinan-kemungkinan operasional, baik terhadap luaran maupun faktor lain yang dapat mempengaruhi jalannya suatu proses. Sedangkan model fungsional yaitu mengkhususkan hubungan-hubungan tertentu di antara berbagai unsur dari suatu proses dan mengumumkannya menjadi hubungan-hubungan yang baru (Cangara, 2014: 44).

Dakwah merupakan kegiatan menyampaikan pesan oleh seorang da'i yang sesuai dengan fenomena kehidupan nyata dengan bersumberkan Al Qur'an dan Hadits kepada pendengar atau mad'u baik secara lisan maupun tulisan. Secara bahasa dakwah berasal dari sebuah kata bahasa arab yang terbentuk dalam masdar, yaitu دعا - يدعو - دعوة (Da'aa - Yad'uu - Da'watan) yang artinya seruan, panggilan, undangan atau do'a. Menurut Abdul Aziz, secara etimlogis (istilah) kata dakwah berarti : (1) Memanggil; (2) Menyeru; (3) Menegaskan atau membela sesuatu; (4) Perbuatan atau perkataan untuk menarik manusia kepada sesuatu; (5) Memohon dan meninta, atau do’a. (Aziz, 1997: 26).

Dalam melakukan dakwah tentunya harus ada unsur-unsur yang berkitan agar proses dakwah tersebut bisa berjalan dengan baik. Berikut ini adalah bagian unsur-unsur dakwah: a) Da’i (Subjek Dakwah). Da’i merupakan panggilan seorang laki-laki (komunikator) yang sudah memiliki kemampuan dan kepribadian baik dalam menyampaikan pesan dakwah kepada para pendengar baik secara langsung maupun tidak. Jika subjek dakwahnya perempuan maka disebut sebagai da'iyah; b) Maudhu (Pesan Dakwah). Maudhu adalah isi materi dari pembicaraan seorang da'i atau daiyah yang mengandung ajakan, pengingat atau nasihat-nasihat baik bagi para pendengar; c) Uslub (Metode Dakwah). Uslub merupakan jalan atau tata cara da'i (daiyah) untuk melakukan dakwah agar pesan dakwah dapat diterima oleh pendengar; d) Wasilah Al Dakwah. Wasilah Al Dakwah adalah media atau perantara yang menghubungkan ide seorang da'i kepada para pendengar, yaitu bias melalui media tradisional maupun modern; e) Mad'u (Objek Dakwah). Mad'u merupakan sasaran dakwah para da'i dalam menyampaikan pesan dakwah yang diberikan tanggungjawab untuk berikhtiar serta memilih mana yang baik dan benar; f) Tujuan Dakwah. Tentunya tujuan dari dakwah ini agar membuahkan hasil yang baik dan menjadi pribadi yang lebih baik pula (Enjang, 2009: 73-98).

Seiring berjalannya waktu, proses penyampaian dakwah tidak hanya dilakukan melalui bentuk ceramah di mimbar saja, melainkan sudah banyak bentuk yang dapat dilakukan untuk melakukan kegiatan dakwah. Diantara bentuk dakwah tersebut adalah sebagai berikut : 1) Tabligh Islam, merupakan bentuk dakwah melaui penyampaian pesan kepada ummat manusia sesuai dengan Al Qur'an dan Sunnah; contoh tabligh yang biasa dilakukan oleh Rasulullah SAW adalah Khithabah dan Kitabah; 2) Irsyad Islam, merupakan bentuk dakwah melalui bimbingan atau penyuluhan baik secara individu maupun kelompok; 3) Tadbir Islam, merupakan bentuk dakwah melalui pengurusan atau 
pengelolaan kelembagaan; 4) Tathwir Islam, merupakan bentuk dakwah melalui pengembangan kehidupan manusia, baik dari segi sumber daya manusianya, lingkungan, pranata social, ekonomi dan aspek kultur universal (Enjang, 2009: 52-62).

Dakwah dapat dilakukan dengan model tertentu oleh siapapun asalkan sesuai dengan sumber Al Qur'an dan Hadits. Di Indonesia melakukan kegiatan dakwah, kini tidak hanya di majlis-majlis ta'lim saja atau di tempat-tempat bidang keagamaan. Namun berdasarkan perkembangan zaman, di instansi-instansi pun sekarang banyak yang suka melakukan kegiatan dakwah.

Instansi dalam Kamus Besar Bahasa Indonesia (KBBI) berarti 1 hk. tingkatan (pengadilan); 2 badan pemerintahan (umum) spt jawatan-jawatan, kantor dsb; rumah - , rumah untuk para pegawai (Poerdawarminta, 1984: 558) Secara bahasa, pemerintah diartikan dari kata perintah yaitu identik dengan melakukan pekerjaan yang telah diperintahkan (menyuruh). Tetapi setelah diberi awalan pe- menjadi pemerintah yang berarti badan atau suatu organisasi yang mengurus segala hal yang berhubungan dengan instansi pemerintahan. Dan setelah ditambah dengan akhiran "-an" menjadi pemerintahan yang berarti perbuatan, cara atau perihal (Syafiie, 2014: 8).

TNI AU memiliki tugas Negara untuk mempertahankan dan mensejahterakan bangsa khususnya bangsa Indonesia agar menjadi bangsa dan negara yang lebih maju dan berkembang. Sehingga, kegiatan dakwah sangat cocok dilakukan sebagai pondasi agar memiliki jiwa dan raga yang kuat. Selain memiliki raga yang kuat dalam berjuang, seorang TNI harus benar-benar memiliki jiwa keimanan yang kuat agar bisa lebih kokoh dan tidak mudah tergoyahkan dengan rintangan apapun. Karena kuatnya iman seseorang akan membuat dirinya menjadi lebih tegas dan tegar dalam menghadapi berbagai masalah.

Melakukan kegiatan dakwah di lingkungan instansi pemerintah atau kantor pemerintahan, baik mereka yang Pegawai Negeri Sipil (PNS), TNI maupun Polri atau pejabat dalam berbagai tingkatannya memiliki tantangan yang tidak mudah. Sehingga diperlukan model dakwah yang benar-benar mudah diterapkan dalam kegiatan dakwah di instansi pemerintah (Mustofa, 2012: 69).

Bentuk dakwah yang biasa dilakukan di TNI AU adalah dengan menggunakan Irsyad Islam (bimbingan atau penyuluhan) yang penyampaian pesannya melalui tabligh. Tabligh terbagi menjadi dua yaitu Khithobah (Public Speaking) dan Kitabah (Menulis). Diantara kedua Tabligh tersebut dakwah yang sering digunakan adalah Khithobah (public speaking).

Khithobah merupakan bahasa Arab yang berasal dari akar katanya: - خَطَبَ يَخطُُْ - خِطَابًَُ (Khathaba, Yakbthubu, Kbithabatan atau Kbithaabatan), yang memiliki arti berkhutbah, berpidato, meminang, melamar, bercakap-cakap, mengirim 
N.H.G. Putri, A.A.Sulthonie \& D. Solahudin

surat. ${ }^{1}$ Sedangkan dalam KBBI mengartikan bahwa khithobah sebagai pidato terutama tentang menguraikan sesuatu ajaran Islam. Dari segi istilah khithobah menurut Harun Nasution rasionalis Islam Indonesia, mengatakan bahwa khithobah adalah ceramah atau pidato yang mengandung penjelasan-penjelasan tentang sesuatu hal atau beberapa masalah yang disampaikan oleh seseorang di hadapan sekelompok orang atau khalayak. Sedangkan menurut Syeikh Al Jurjani, Khithobah, adalah suatu upaya yang menimbulkan rasa ingin tahu terhadap orang lain tentang suatu perkara yang berguna baginya baik mengenai urusan dunia maupun akhirat (Sukayat, 2009: 93).

Ada beberapa bentuk kegiatan model Khithobah, yaitu Khithobah Diniyah dan Khithobah Ta'tsiriyah. Khithobah Diniyah adalah khithobah yang terkait langsung dengan ibadah mahdhah. Zaman sekarang khithobah Diniyah disebut dengan khutbah, seperti : Khutbah Idul Fitri, Khutbah Idul Adha, Khutbah Jum'at, Khutbah Istisqa, Khutbah Gerhana Bulan, Khutbah Gerhana Matahari, dan Khutbah Wukuf di Arafah. Sedangkan Khithobah Ta'tsiriyah adalah khithobah yang tidak terkait langsung dengan pelaksanaan ibadah mahdhah, seperti berbagai macam kegiatan tabligh akbar misalnya pada peringatan Maulid Nabi, Isra Mi'raj, peringatan tahun baru 1 Muharam, Nuzulul Qur'an, Peringatan hari kemerdekaan, tasyakur pernikahan, khitanan dan lain sebagainya (Sukayat, 2009: 128).

Khithobah inilah yang relative dikenal masyarakat dengan sebutan Ceramah. Berdasarkan informasi wahyu dari beberapa ayat dalam Al Qur'an, proses Khithobah ini melibatkan unsur-unsur sebagaimana diperlihatkan pada gambar berikut:

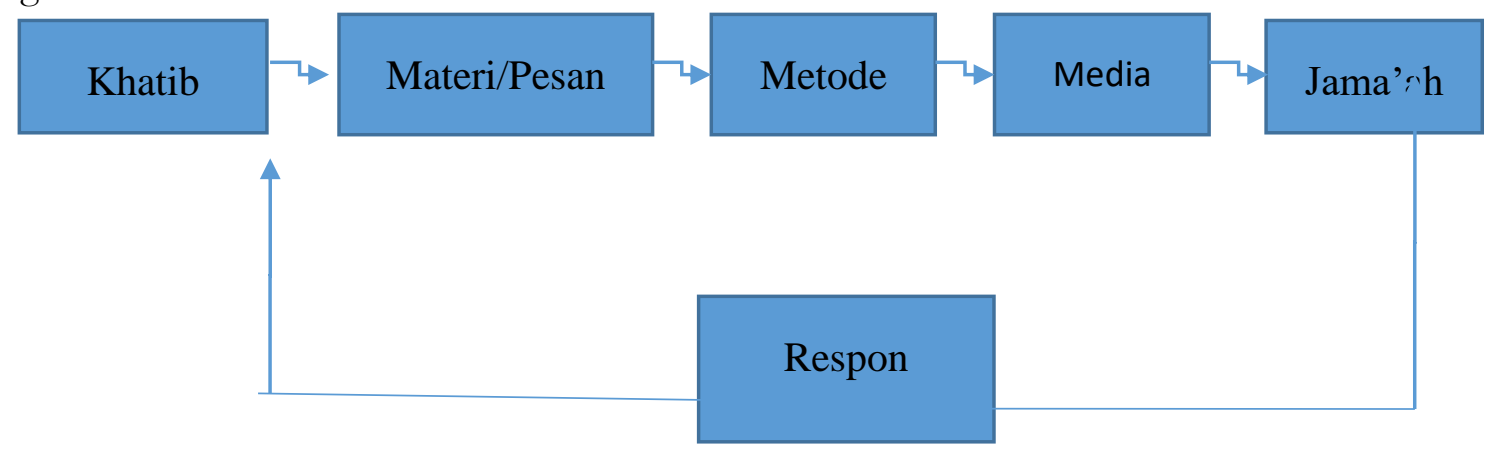

Gambar 1.: Proses Khithobah

Kegiatan khithobah akan lebih luas jangkauannya ketika didukung oleh media-media komunikasi elektronik modern, umpamanya disiarkan langsung oleh stasiun televisi, radio atau dibuat dan diperbanyak dalam bentuk kaset,

\footnotetext{
${ }^{1}$ Ahmad Munawir Warson, Al Munawir Kamus Bahasa Arab-Indonesia, (Yogyakarta: Ponpes Al Munawir, 1984), hal. 376
} 
VCD, DVD, dan lain-lain (Enjang, 2009: 59).

\section{HASIL DAN PEMBAHASAN}

Pada awalnya Pangkalan TNI AU Wiriadinata merupakan peninggalan penjajahan Belanda dan Jepang dengan nama yang lebih popular yaitu Lapangan Udara Cibeureum Tasikmalaya. Tepatnya berada di daerah Jl. Letkol Basyir Surya, Cibeureum Tasikmalaya. Pangkalan Udara ini dibangun dengan tujuan untuk dipergunakan sebagai tempat landing dan take off pesawat-pesawat Militer Belanda, begitu juga pada masa pendudukan Jepang. Hal ini sangat bermanfaat dan besar sekali peranannya untuk kelanjutan perjuangan Bangsa Indonesia khususnya dibidang Matra Udara.

Kemudian, pada tanggal 2 November 1945 OMU I Basir Surya diangkat menjadi Komandan Pangkalan Udara Cibeureum Tasikmalaya yang Pertama dengan Surat Keputusan No. 33/Peng tanggal 30 November 1946 yang merangkap sebagai Kepala Tekhnik Udara, Pembukaan Pangkalan Cibeureum Tasikmalaya yang jatuh pada tanggal 13 April 1946 diadakan pameran dan Pekan Penerbangan dengan tujuan untuk memasyarakatkan Minat Dirgantara dikalangan remaja daerah, selanjutnya pada tanggal 15 April 1946 dilaksanakan penerbangan formasi dan lintas udara antar daerah-daerah Yogyakarta, Tasikmalaya, Wirasaba, Sala, Madiun, dan Malang. Penerbangan-penerbangannya adalah Husein Sastranegara, Tugiyo, Santoso, dan Wim Prajitno.

Dinamakan menjadi Lanud Wiriadinata dari Pangkalan Cibeureum karena Pada peringatan Hari Angkatan Perang R.I di Pangkalan Udara Cibeureum Tasikmalaya yang turut berjasa dalam pengembangan kedirgantaraan, maka pada tanggal 7 Oktober 1959 diadakan Upacara dengan pertunjukan Air Show dan Joy-Ride yang waktu itu dibuka langsung Letnan Kolonel Udara A. Wiriadinata Komandan Pangkalan Udara Husein Sastranegara selaku wakil KSAU pada Upacara tersebut. Rakyat Tasikmalaya telah menyadari pentingnya penerbangan baik untuk perhubungan Udara guna terwujudnya ekonomi maupun pada social yang bersendikan Proklamasi 17 Agustus 1945. Dalam sambutan Letnan Kolonel Udara A. Wiriadinata menegaskan arti daya guna dan kemampuan banteng Nasional di Udara yang kita miliki atas hasil revolusi Kemerdekaan perlu dipupuk demi kejayaan dan keagungan bangsa Negara RI.

Adapun tugas pokok atau tugas utama dari Pangkalan TNI AU Wiriadinata adalah sebagai satuan jajaran Koopsau I mempunyai tugas pokok menyiapkan dan melaksanakan pembinaan maupun pengoperasian seluruh satuan dalam jajarannya dan pembinaan potensi dirgantara serta menyelenggarakan dukungan operasi bagi satuan lainnya.

Suatu instansi tidak akan berdiri kokoh tanpa adanya kerjasama dan tujuan (visi misi). TNI AU Wiriadinata memiliki tujuan (visi dan misi) yang baik untuk 
Negara Indonesia khususnya personel dan warga sekitar Lanud Wiriadinata. Visinya adalah agar terwujudnya Lanud Wiriadinata yang mampu menyelanggarakan operasi udara dan mampu memberdayakan wilayah pertahanan Dirgantara di Priangan Timur dan diwakili oleh prajurit yang disiplin, profesional dan sejahtera. Sedangkan misinya adalah sebagai berikut: 1) Melaksanakan perintah operasi sesuai rencana operasi; 2) Menyelenggarakan dukungan operasi penerbangan; 3) Menjaga dan memelihara asset TNI AU yang menjadi tanggung jawab Lanud Wiriadinata 4) Melaksanakan latihan secara bertahap, berlanjut dan berkesinambungan; 5) Menyelenggarakan pemberdayaan wilayah pertahanan Dirgantara dengan Binpotdirga untuk meningkatkan minat Dirgantara dan menggali Potensi Dirgantara Wilayah Priangan Timur; 6) Menyelenggarakan pemeliharaan asset, sarana dan prasarana serta fasilitas dukungan yang ada di Lanud Wiriadinata; 7) Menyelenggarakan pembinaan, pendidikan dan perawatan personel Lanud Wiriadinata.

Untuk memperoleh hasil penelitian terkait judul di atas, penulis melakukan wawancara dengan Komandan Lanud Wiriadinata, Letkol Pnb Safeano Cahyo Wibowo S.T. Exc. Dipl. S.S. sebagai pimpinan komando dalam pelaksanaan berbagai macam kegiatan di Lanud Wiriadinata. Kegiatan wawancara tersebut dilakukan sesuai dengan kebutuhan hasil pembahasan yang mengarah kepada fokus penelitian agar pembahasan tidak melebar luas.

Penulis melakukan wawancara dengan Komandan seputar kegiatan dakwah di Lanud Wiriadinata dan kegiatan-kegiatan lain yang bersangkutan dengan dakwah. "Dari sekian banyak kegiatan-kegiatan yang dilakukan di Lanud Wiriadinata, kegiatan dakwah merupakan salah satu kegiatan dinas bidang keagamaan baik pada jam kerja maupun di luar jam kerja. Bentuk kegiatan dakwah tersebut dengan cara khithobah/public speaking (ceramah) dan dilaksanakan pada saat apel pagi, kultum setelah shalat berjamah baik shalat wajib maupun shalat sunnat, serta ceramah pada kegiatan-kegiatan besar Islam (PHBI). Kegiatan tersebut diikuti oleh seluruh personel dan yang mengatur rangkaian kegiatannya adalah Bintal dengan dibantu oleh Paroh." Ujar Komandan Lanud Wiriadinata.

Selain itu penulis juga melakukan wawancara dengan Kasubsi Bintal PNS Drs. Nurul Mutaqin, dan PNS H. Agus Husin S, S.Th.I, sebagai ketua dan pelaksana kegiatan dakwah di Lanud Wiriadinata. Berdasarkan hasil wawancara dengan Komandan Lanud Wiriadinata Letkol Pnb Safeano Cahyo Wibowo, S.T. Exc Dipl S.S, beliau menyatakan bahwa kegiatan yang ada di Lanud Wiriadinata ini biasa dilakukan pada saat jam kerja dan ada pula yang dilakukan di luar jam kerja. Kegiatan yang biasa dilakukan pada saat jam kerja adalah kegiatan yang berhubungan dengan program kerja masing-masing personel Lanud Wiriadinata. Pelaksanaannya dimulai pada hari Senin sampai Jum'at dengan diawali apel pagi pada pukul 07.00 s.d 07.30 WIB. Setelah apel pagi selesai, seluruh personel 
Lanud Wiriadinata mulai masuk masjid untuk melaksanakan shalat sunat Dhuha yang kemudian dilanjut ke kantornya masing-masing untuk mengerjakan seluruh program kerja yang telah ditugaskan. Sekitar pukul 12.00 atau saat waktunya isoma (istirahat, shalat, makan), seluruh personel diarahkan untuk memasuki masjid dan melaksanakan shalat Dzuhur berjamaah. Waktu istirahat tersebut kurang lebih selama satu jam. Namun, karena seluruhnya diwajibkan shalat Dzuhur berjamaah di Masjid Rifatul Hasanah Lanud Wiriadinata, waktu untuk masuk kembali ke Kantor yang lazimnya pukul 13.00 ditambah 30 menit jadi 13.30 WIB untuk melanjutkan pekerjaannya. Kegiatan tersebut diakhiri dengan shalat berjamaah yang langsung disambung apel sore atau apel perpulangan Kantor pada pukul 16.00 WIB.

Dalam melakukan pekerjaannya, seluruh personel Lanud Wiriadinata diberikan arahan dan bimbingan langsung dari atasannya. Dan dari masingmasing mereka sudah diberikan fasilitas berupa ruangan masing-masing dengan berbagai kelengkapan kerjanya seperti computer, wifi, printer, dispenser, dan alat ATK lainnya.

Selain kegiatan di atas, ada pula kegiatan dalam bidang keagamaan yaitu seperti shalat wajib 5 waktu secara berjamaah di masjid beserta shalat-shalat sunatnya, pengajian, dakwah dengan ceramah kerohanian, ziarah dan silaturahmi. Yang bertugas mengurus kegiatan tersebut adalah Bintal. Bintal merupakan salah satu personel yang menyelenggarakan seluruh kegiatan pembinaan mental personel. Fungsinya untuk perawatan personel sebagai upaya membentuk, memelihara, meningkatkan dan memantapkan kondisi jiwa prajurit serta PNS yang memberikan kontribusi jaminan kesiapan personel secara optimal. Dalam rangka meningkatkan mental serta jiwa anggota Pangkalan TNI AU Wiriadinata maka dilaksanakan program pembinaan mental rohani, ideologi, tradisi kejuangan dan pembinaan mental psikologi sesuai ketentuan yang berlaku di Pangkalan TNI AU Wiriadinata dalam mencapai kinerja personel yang optimal.

Dalam waktu wawancara yang bersamaan Letkol Pnb Safeano Cahyo Wibowo, S.T. Exc. Dipl. S.S. Komandan Lanud Wiriadinata menjelaskan bahwa proses kegiatan dakwah tersebut dilakukan melalui beberapa tahap pelaksanaan yaitu perencanaan, pengorganisasian, pelaksanaan dan evaluasi dengan cara Khithobah (public speaking). Dalam tahap perencanaan, Perwira Rohani atau yang sering disebut Paroh dan Bintal (Pembina Mental) harus benar-benar merencanakan beberapa hal terkait pelaksanaan khithobah di Lanud Wiriadinata baik dari mulai pemilihan waktu, tempat, sarana, penceramah, materi dan lain sebagainya. Selanjutnya pada tahap pengorganisasian Bintal membentuk beberapa struktur keorganisasian agar dalam pelaksanaan kegiatannya berjalan dengan lancar. Struktur keorganisasian tersebut disesuaikan dengan kegiatan dakwah yang akan dilaksanakan. Kemudian pada tahap pelaksanaan kegiatan 
tersebut dilaksanakan melalui persiapan yang telah direncanakan oleh struktur keorganisasian dengan semaksimal mungkin. Pelaksanaan dakwah tersebut biasanya pada saat apel pagi, setelah shalat berjamaah, di luar jam kerja Kantor, atau secara kondisional, misalnya pengajian mingguan, bulanan di Komplek Trikora Lanud Wiriadinata. Dan yang terakhir adalah tahap evaluasi, inilah yang menjadi tolak ukur untuk menilai bagaimana kegiatan tersebut terjadi dari mulai perencanaan hingga pelaksanaan.

Seluruh kegiatan keagamaan atau yang berkaitkan dengan dakwah diatur sepenuhnya oleh Bintal yang dibantu oleh Rohaniawan Islam dengan memberikan bimbingan tentang ajaran Islam melalui pendidikan, ceramah dan dakwah secara lisan (Khithobah). Selain itu, Bintal juga memberikan bimbingan tentang pengamalan ajaran Agama Islam baik sebagai perorangan maupun kelompok masyarakat. Serta menciptakan kerukunan hidup antar ummat beragama di lingkungan TNI AU khususnya di Lanud Wiriadinata.

Melaksanakan kegiatan dakwah bukanlah suatu hal yang mudah seperti berbicara pada umumnya. Namun, menurut Rohaniawan Islam Lanud Wiriadinata PNS H. Agus Husin S, S.Th.I, bahwa secara naluri manusia menginginkan kesejahteraan dan keselamatan baik pada kehidupan di dunia sekarang ini maupun pada kehidupan akhirat nanti. Agama Islam telah memberikan tuntunan-tuntunan yang luas untuk keperluan ini. Disinilah letak peranan dan tugas Rohaniawan Islam yang dibantu oleh Bintal untuk memberikan pembinaan dan bimbingan keagamaan yang bersumberkan ajaranajaran Agama Islam khususnya di Lanud Wiriadinata. Sehingga antara Bintal dan Rohaniawan di Lanud Wiriadinata ini saling membantu dan bekerjasama dalam menjalankan tugasnya.

Setelah selesai melakukan wawancara terkait fokus penelitian yang pertama tentang proses kegiatannya, penulis melakukan wawancara lanjutan terkait bentuk kegiatan khithobah dengan Kasubsi Bintal Lanud Wiriadinata PNS Drs. Nurul Mutaqin selaku ketua dalam pelaksanaan seluruh kegiatan keagamaan khususnya pada kegiatan dakwah di Lanud Wiriadinata.

Dalam hasil wawancaranya Kasubsi Bintal Lanud Wiriadinata PNS Drs. Nurul Mutaqin menjelaskan bahwa bentuk dakwah yang dilakukan di Lanud Wiriadinata melalui Tabligh Khithobah atau menyampaikan pesan dakwah secara langsung melalui lisan kepada seluruh personel yang ada di lingkungan sekitar Lanud Wiriadinata.

Berikut ini adalah ragam kegiatan Khithobah yang ada di Lanud Wiriadinata: a) Ceramah pembinaan rohani (binroh): ceramah pembinaan rohani dilaksanakan 2 kali dalam sebulan bertempat di lapangan apel/Masjid Rifatul Hasanah Komplek perkantoran Lanud Wiriadinata; b) Ceramah pembinaan tradisi kejuangan: ceramah pembinaan mental tradisi kejuangan dilaksanakan 1 kali dalam sebulan bertempat di lapangan apel Lanud Wiriadinata; c) Ceramah 
pembinaan mental ideologi: ceramah pembinaan mental ideologi dilaksanakan 1 kali dalam sebulan bertempat di lapangan apel Lanud Wiriadinata; d) Ceramah pembinaan mental psikologi: ceramah pembinaan mental psikologi dilaksanakan 1 kali dalam sebulan bertempat di lapangan apel Lanud Wiriadinata; e) Ceramah PHBI atau Peringatan Hari Besar Islam: ceramah PHBI ini dilaksanakan sesuai dengan waktu kegiatan tersebut, misalnya Ceramah Idul Fitri dilaksanakan pada saat Hari Raya Idul Fitri, Ceramah Idul Adha dilaksanakan pada saat Hari Raya Idul Adha dan lain sebagainya; f) Kegiatan ceramah yang dilaksanakan di luar jam kerja Lanud Wiriadinata: diantara kegiatan ceramah di luar jam kerja misalnya pengajian ibu-ibu setiap hari Selasa sore, pengajian bapak-bapak setiap malam Jum'at, pengajian anak-anak setiap bulan Ramadhan di Masjid Asy Syakirin Komplek Asrama Trikora Lanud Wiriadinata.

Masih dalam wawancara yang sama kepada Kasubsi Bintal PNS Drs. Nurul Mutaqin terkait faktor-faktor yang menjadi pendukung kegiatan di Lanud Wiriadinata khususnya dalam kegiatan keagamaan. Beliau menyatakan bahwa dalam kegiatan keagamaan di Lanud Wiriadinata salah satunya dakwah itu bisa tercipta tentunya karena ada faktor pendukung baik secara internal maupun eksternal. Dan yang bertugas untuk mewujudkan kegiatan tersebut adalah Kasubsi Bintal dan jajarannya di Lanud Wiriadinata.

Kasubsi Bintal mengatakan bahwa tanpa dukungan dari personel maupun masyarakat setempat, kami selaku pengurus Bintal akan kesulitan dalam pelaksanaannya. Alhamdulillah berkat do'a dan dukungan dari semua pihak kegiatan tersebut bisa berjalan dengan lancar.

Suatu kegiatan tidak akan terlaksana tanpa adanya dukungan baik secara internal maupun eksternal. Seperti halnya kegiatan dakwah di Lanud Wiriadinata tidak akan berjalan tanpa adanya dukungan. Berikut ini adalah beberapa hal yang menjadi faktor pendukung kegiatan dakwah secara khithobah di Lanud Wiriadinata: a) Faktor lingkungan yakni daerah Tasikmalaya yang dikenal dengan julukan kota santri karena banyaknya pesantren yang dibangun. Lingkungan yang mendukung akan membuahkan hasil yang baik bagi yang menempatinya; b) Pemimpin (Komandan) yang mengerti tentang agama dan menginginkan seluruh personelnya lebih baik dalam segala hal; c) Kerjasama yang baik antara Bintal dengan Paroh sebagai petugas dan pelaksana kegiatan khithobah; d) Personel Lanud Wiriadinata yang saling mendukung satu sama lainnya baik antara sesama muslim maupun yang muslim dengan non muslim; e) Sarana dan prasarana tempat kegiatan khithobah yang memadai; f) Dorongan dari dalam diri masingmasing personel untuk berubah menjadi diri yang lebih baik dari sebelumnya; $\mathrm{g}$ ) Adanya nasihat atau saling mengingatkan dalam segala hal kebaikan sekaligus mengajak secara perlahan; h) Banyaknya silaturahmi ke beberapa pesantren yang dapat memudahkan untuk mengundang para Kiyai atau pimpinan pesantren 
tersebut agar hadir menyampaikan pesan dakwah (berceramah) di Lanud Wiriadinata pada kegiatan tertentu; i) Anggota yang ada di Lanud Wiriadinata mayoritas beragama Islam; j) Terciptanya toleransi yang baik di lingkungan Lanud Wiriadinata; k) Tidak adanyanya paksaan dalam melaksanakan kegiatan dakwah tetapi terus memberikan nasihat yang baik tanpa membenci satu sama lainnya.

Hasil penelitian ini menemukan tentang proses kegiatan khithobah di Lanud Wiriadinata, bentuk kegiatan khithobah di Lanud Wiriadinata dan faktor pendukung kegiatan khithobah di Lanud Wiriadinata.

\section{Proses Kegiatan Khithobah di Lanud Wiriadinata}

Dalam dakwah, penyampaian pesan harus diperhatikan, apalagi penyampaian pesan secara langsung (Khithobah) perlu diperhatikan pembicaraannya. Kata-kata yang salah jika telah dilontarkan, maka akan sulit dihapus dari pendengaran mad'u bahkan bisa menimbulkan perpecahan jika kata tersebut menyinggung perasaan orang lain. Sehingga pesan dakwah, harus disampaikan dengan katakata yang lemah lembut, benar, jujur, tidak bohong, tidak berbeli-belit, mudah dimengerti, dan santun artinya tidak kasar (Mubasyaroh, 2017: 319).

Proses kegiatan dakwah di Lanud Wiriadinata dilakukan melalui beberapa tahap yang telah disiapkan oleh Bintal dan Paroh yang bertanggung jawab dalam kegiatan dakwah di Lanud Wiriadinata. Persiapan tersebut dari mulai perencanaan hingga pelaksanaaan dan evaluasi dari pelaksanaannya. Komandan Lanud Wiriadinata Letkol Pnb Safeano Cahyo Wibowo S.T. Exc Dipl S.S yang memimpin dan mengkoordinir seluruh kegiatan di Lanud Wiriadinata termasuk kegiatan dakwah.

Dakwah merupakan kegiatan menyeru atau mengajak untuk melakukan perbuatan baik dan mencegah perbuatan munkar. Dakwah biasanya di lakukan di masjid atau di berbagai majlis ta'lim secara langsung, misalnya dengan pengajian, Tabligh Akbar dan lain sebagainya. Namun, di Indonesia kegiatan dakwah tidak hanya dilakukan di majlis ta'lim saja. Sekarang sudah banyak instansi umum misalnya instansi Pemerintah yang melakukan kegiatan dakwah. Salah satu instansi Pemerintah yang melakukan kegiatan dakwah adalah seperti instansi TNI AU.

Dari sekian banyak TNI AU yang ada di Indonesia, Lanud Wiriadinata merupakan salah satu instansi umum yang melakukan model kegiatan dakwah. Model merupakan suatu cara untuk menggambarkan atau menunjukkan sebuah objek tertentu yang berkaitan dengan berbagai aspek dari sebuah proses, pemikiran dan hubungan antara unsur pendukungnya. Sebuah model dapat dikatakan berhasil, apabila seluruh aspek mendukung terjadinya sebuah proses.

Berdasarkan hasil penelitian dan wawancara dari Letkol Pnb Safeano Cahyo Wibowo, S.T. Exc. Dipl. S.S. selaku Komandan Lanud Wiriadinata yang 
ke-31 yang berasal dari Surabaya dan lulusan Akademi Udara tahun 1998. Beliau juga pernah menjabat sebagai Komandan Skadron 0104 di Yogyakarta. Komandan Lanud Wiriadinata ke-31 ini memiliki inspirasi dalam hidupnya untuk terus berbagi menyebarkan kebaikan berdasarkan pengalamannya yang sibuk dengan jam terbang tetapi masih bisa melaksanakan ibadah kepada Allah SWT.

Pada prosesnya, yang bertugas dalam pelaksanaan kegiatan dakwah di Lanud Wiriadinata ini adalah Bintal (Pembina Mental) dan Paroh (Perwira Rohani/Rohaniawan Islam). Proses tersebut dilakukan dalam beberapa tahap yaitu perencanaan, pengorganisasian, pelaksanaan dan evaluasi. Dalam proses perencanaan Bintal dan Paroh merencanakan berbagai kegiatan dakwah yang akan dilaksanakan di Lanud Wiriadinata. Setelah perencanaan tersebut dirancang barulah menyusun pengorganisasian untuk menentukan siapa saja yang akan terlibat dalam pelaksanaannya. Kemudian, kegiatan dakwah dapat dilaksanakan sesuai perencanaan dan pengorganisasian yang telah dibuat. Dan setelah semuanya dilaksanakan barulah diakhir kegiatan seluruh organisasi yang terlibat mengadakan evaluasi tentang kegiatan dakwah tersebut (Cangara, 2014: 43).

\section{Bentuk Kegiatan Khithobah di Lanud Wiriadinata}

Dakwah di Lanud Wiriadinata ini dilakukan melalui Irsyad Islam (pembinaan) oleh Bintal dan Paroh yang penyampaian pesannya dengan model Tabligh. Bentuk kegiatan secara public speaking atau yang lebih sering dikenal dengan ceramah/pidato. Ceramah tersebut biasanya disampaikan pada saat apel pagi, kultum ba'da shalat atau dalam kegiatan lainnya.

Sebagaimana telah dijelaskan sebelumnya bahwa Tabligh merupakan bentuk dakwah melalui penyampaian pesan kepada ummat manusia sesuai dengan Al Qur'an dan Sunnah; contoh tabligh yang biasa dilakukan oleh Rasulullah SAW adalah Khithabah dan Kitabah. Khithobah adalah kegiatan menyampaikan pesan secara langsung melalui lisan. Sedangkan Kitabah penyampaian pesannya melalui tulisan.

Ada dua bentuk kegiatan Khithobah, yaitu Khithobah Diniyah dan Khithobah Ta'tsiriyah. Khithobah Diniyah adalah khithobah yang terkait langsung dengan ibadah mahdhah. Zaman sekarang khithobah Diniyah disebut dengan khutbah, seperti : Khutbah Idul Fitri, Khutbah Idul Adha, Khutbah Jum'at, Khutbah Istisqa, Khutbah Gerhana Bulan, Khutbah Gerhana Matahari, dan Khutbah Wukuf di Arafah. Sedangkan Khithobah Ta'tsiriyah adalah khithobah yang tidak terkait langsung dengan pelaksanaan ibadah mahdhah, seperti berbagai macam kegiatan tabligh akbar misalnya pada peringatan Maulid Nabi, Isra Mi'raj, peringatan tahun baru 1 Muharam, Nuzulul Qur'an, Peringatan hari kemerdekaan, tasyakur pernikahan, khitanan dan lain sebagainya. Khithobah inilah yang relative dikenal masyarakat dengan sebutan Ceramah. 
Dari hasil penelitian dan wawancara dengan Kasubsi Bintal Lanud Wiriadinata PNS Drs. Nurul Mutaqin bahwa model kegiatan dakwah di Lanud Wiriadinata dilakukan melalui ceramah-ceramah. Dan pesan ceramah tersebut disampaikan secara lisan dari Komandan atau Kepala-kepala personel dalam beberapa kegiatan.

Berikut ini adalah kegiatan Khithobah (Ceramah) periode Komandan ke31 Lanud Wiriadinata Letkol Pnb Safeno Cahyo Wibowo, S.T.Exc.Dipl.S.S.: a) Shalat Dhuha Istighotsah (meminta pertolongan) dan do'a bersama; b) Khutbah Jum'at dan program sedekah setiap hari Jum'at; c) Kultum setiap ba'da shalat berjama'ah; d) Program gerakan wajib Shalat Subuh berjama'ah; e) Program Shalat Sunnat Tahajud di Masjid Asy Syakirin; f) Majlis mudzakarah; g) Program MQ (Murotarul Quran); h) Program HQ (Hifdzil Quran); i) Program bantuan sosial pondok pesantren atau lembaga keagamaan; j) Program haji dan umroh untuk warga Lanud Wiriadinata bekerjasama dengan PT Arminareka; k) Program Panti sosial pengobatan masal Purnawirawan Warakauri; l) Program do'a bersama yang menghadirkan tokoh dari berbagai macam agama; m) Program kegiatan Ramadhan (Sukayat, 2009: 94).

\section{Faktor Pendukung Kegiatan Khithobah di Lanud Wiriadinata}

Suatu kegiatan tidak akan terlaksana tanpa adanya dukungan baik secara internal maupun eksternal. Seperti halnya kegiatan dakwah di Lanud Wiriadinata tidak akan berjalan tanpa adanya dukungan.

Berikut ini adalah beberapa hal yang menjadi faktor pendukung kegiatan dakwah secara kbithobah di Lanud Wiriadinata: a) Faktor lingkungan yakni daerah Tasikmalaya yang dikenal dengan julukan kota santri karena banyaknya pesantren yang dibangun. Lingkungan yang mendukung akan membuahkan hasil yang baik bagi yang menempatinya; b) Pemimpin (Komandan) yang mengerti tentang agama dan menginginkan seluruh personelnya lebih baik dalam segala hal; c) Kerjasama yang baik antara Bintal dengan Paroh sebagai petugas dan pelaksana kegiatan khithobab; d) Personel Lanud Wiriadinata yang saling mendukung satu sama lainnya baik antara sesama muslim maupun yang muslim dengan non muslim; e) Sarana dan prasarana tempat kegiatan kbithobah yang memadai; f) Dorongan dari dalam diri masing-masing personel untuk berubah menjadi diri yang lebih baik dari sebelumnya; g) Adanya nasihat atau saling mengingatkan dalam segala hal kebaikan sekaligus mengajak secara perlahan; h) Banyaknya silaturahmi ke beberapa pesantren yang dapat memudahkan untuk mengundang para Kiyai atau pimpinan pesantren tersebut agar hadir menyampaikan pesan dakwah (berceramah) di Lanud Wiriadinata pada kegiatan tertentu; i) Anggota yang ada di Lanud Wiriadinata mayoritas beragama Islam; j) Terciptanya toleransi yang baik di lingkungan Lanud Wiriadinata; k) Tidak adanyanya paksaan dalam melaksanakan kegiatan dakwah tetapi terus memberikan nasihat yang baik 
tanpa membenci satu sama lainnya.

Selain faktor pendukung, komunikasi dakwah dengan baik dapat membantu meningkatkan pemahaman pendengar pada pesan dakwah yang disampaikan. Karena pesan dakwah yang disampaikan akan mudah dimengerti oleh masyarakat umum apabila pesan-pesan dakwah tersebut masuk akal serta sesuai dengan Al Qur'an dan Hadits. Bagi personel Lanud Wiriadinata kegiatan dakwah sangat penting dilakukan untuk menjadikan lebih kuat dalam segala hal. Selain, kuat dalam mempertahankan kesejahteraan Negara sebagai TNI pembela Negara Republik Indonesia, personel Lanud Wiriadinata ini juga memiliki keteguhan hati dalam membela Islam dengan toleransi yang baik. (Mubasyaroh, 2017: 314).

\section{PENUTUP}

Berdasarkan uraian yang telah dipaparkan di atas, maka dapat disimpulkan bahwa kegiatan dakwah di Lanud Wiriadinata ini dilakukan oleh Bintal. Bintal merupakan staf yang ada di Lanud Wiriadinata yang bertugas melakukan Pembinaan Mental dan di dalamnya ada beberapa kegiatan bidang keagamaan salah satunya dengan kegiatan dakwah. Dalam melakukan tugasnya Bintal dibantu oleh Paroh (Perwira Rohani). Proses kegiatan dakwah tersebut dilakukan melalui beberapa tahap yaitu tahap perencanaan, tahap pengorganisasian, tahap pelaksanaan dan tahap evaluasi.

Adapun bentuk dakwah yang digunakan di Lanud Wiriadinata ini adalah dengan Irsyad Islam (Pembinaan), yang penyampaian pesan dakwahnya dilakukan dengan cara Tabligh Khithobah. Tabligh khithobah merupakan cara untuk menyampaikan pesan dakwah kepada banyak orang atau khalayak secara langsung melalui lisan. Bentuk dakwah seperti ini popular disebut dengan ceramah atau pidato.

Berjalannya kegiatan dakwah di Lanud Wiriadinata ini tidak terlepas dari dukungan yang ada di sekitarnya baik secara internal maupun eskternal. Dengan dukungan tersebut, sampai sekarang kegiatan dakwah di Lanud Wiriadinata tidak pernah padam. Kegiatan tersebut didukung oleh seluruh personel Lanud Wiriadinata dan masyarakat yang ada di lingkungan sekitarnya.

Suatu kegiatan akan lebih baik jika dilakukan secara kerjasama dengan kompak. Sehingga, demi terciptanya model dakwah yang berkualitas di Lanud Wiriadinata Tasikmalaya, maka penulis mencoba memaparkan beberapa saran yang bisa membangun kegiatan tersebut. Berikut ini adalah beberapa saran yang bisa dipaparkan, diantaranya: 1) Dalam proses kegiatan khithobah yang dilaksanakan di Lanud Wiriadinata ini alangkah lebih baiknya melibatkan seluruh personel Lanud Wiriadinata. Sehingga, yang menjadi penceramah atau penasehat itu tidak hanya yang bertugas saja (Bintal dan Paroh), tetapi seluruhnya diroling 
N.H.G. Putri, A.A.Sulthonie \& D. Solahudin

agar bisa bergantian menyampaikan pesan dakwah meskipun hanya sebentar. Kegiatan ini dilakukan agar seluruh personel Lanud Wiriadinata terbiasa berbicara di depan banyak orang (khalayak) dalam masalah keagamaan dan bisa diterapkan pula di keluarganya masing-masing; 2) Bentuk dakwah yang dilakukan di Lanud Wiriadinata ini pada umumnya berbentuk Irsyad Islam yang penyampaiannya melalui Tabligh Khithobah. Namun, alangkah lebih baiknya jika beberapa kegiatan lainnya seperti bulletin lebih dikembangkan lagi. Sehingga ada variasi dalam melakukan kegiatan dakwahnya; 3) Dari beberapa faktor pendukung yang telah dipaparkan sebelumnya pada BAB III, dalam beberapa kegiatan dakwah yang ada di Lanud Wiriadinata, benar-benar didukung oleh seluruh personel Lanud Wiriadinata baik dari segi materiil maupun non materiil. Jadi tidak hanya mengandalkan dukungan dari pihak-pihak yang terlibat saja. Dan yang paling utama adalah kerjasama yang baik tanpa mengandalkan satu sama lainnya.

Demikianlah saran yang bisa dipaparkan oleh penulis. Semoga dengan adanya pemaparan saran-saran tersebut dapat membangun perkembangan model dakwah di Lanud Wiriadinata Tasikmalaya.

\section{DAFTAR PUSTAKA}

Enjang, A. \& Aliyudin. (2009). Dasar-Dasar Ilmu Dakwah. Bandung: Widya Padjadjaran.

As Salam. (2012). Al Qur'an dan Terjemahnya Edisi 1000 Do'a. Bandung:

Mizan Bunaya Kreativa, Cet-2.

Cangara, H. (2014). Pengantar Ilmu Komunikasi. Jakarta: PT RajaGrafindo Persada, Cetakan ke-14.

Mubasyaroh. (2017). Strategi Dakwah Persuasif dalam Mengubah Perilaku Masyarakat dalam Ilmu Dakwab: Academic Journal for Homiletic Studies, 2(11), 311-324.

Muhyiddin, A; Dindin S; Ahmad Sarbini; Zaenal Mukarom; Acep Aripudin, 2014. Kajian Dakwah Multiperspektif, Bandung: PT Remaja Rosdakarya.

Mulyana, D. (2013). Ilmu Komunikasi. Bandung: PT Remaja Rosdakarya, Cetakan ke-17.

Munawwir, A. (1984). Kamus Al Munawnir Arab-Indonesia Terlengkap. Yogyakarta: Ponpes Al Munawwir.

Mustofa, K. (2012). Dakwah Di Balik Kekuasaan. Bandung: PT Remaja Rosdakarya.

Poerwadarminta, W.J.S. (1984). Kamus Umum Babasa Indonesia. Jakarta: PN Balai Pustaka.

Rakhmat, J. (2012). Metode Penelitian Komunikasi. Bandung: PT Remaja Rosdakarya, Cetakan ke-15.

Sukayat, T. (2009). Quantum Dakwah. Jakarta: Rineka Cipta. 
Sumaryadi, D. (2003). Sejarah Lanud Wiriadinata. Tasikmalaya: Lanud Wiriadinata. Syafiie', I. (2014). Ilmu Pemerintahan. Jakarta: PT Bumi Aksara, Cet. Ke-2.

Syafiie', I. (2007). Imu Pemerintahan Edisi Revisi, Bandung: Mandar Maju, Cet. Ke3. 